\title{
CRITICAL ASPECTS IN EXPLORING TIME ANALYSIS FOR THE VOLTAMMETRIC ESTIMATION OF KINETIC PARAMETERS OF SURFACE ELECTRODE MECHANISMS COUPLED WITH CHEMICAL REACTIONS
}

\author{
Rubin Gulaboski ${ }^{1 *}$, Valentin Mirčeski ${ }^{2,3}$, Milivoj Lovrić $^{4}$ \\ ${ }^{1}$ Faculty of Medical Sciences, Goce Delčev University, Štip, Macedonia \\ ${ }^{2}$ Institute of Chemistry, Faculty of Natural Sciences and Mathematics, Ss. Cyril and Methodius University, \\ Arhimedova 5, 1000 Skopje, Macedonia \\ ${ }^{3}$ Faculty of Chemistry, Department of Inorganic and Analytical Chemistry, University of Lódź, Tamka 12, \\ 91-403 Lódź, Poland \\ ${ }^{4}$ Divkovićeva 13, Zagreb 10090, Croatia \\ rubin.gulaboski@ugd.edu.mk
}

\begin{abstract}
The accurate determination of the rate constant related to the electron transfer step of so-called "surface redox active compounds" by voltammetric measurements is very important because it is linked to the reactivity and stability of many biological and chemical systems such as redox enzymes, vitamins, hormones, and many more. Evaluation of the kinetics of the electron transfer is often challenging, especially when chemical equilibria are coupled to the electron transfer step. In this work, we theoretically consider some critical aspects of the time-related methodologies in square-wave voltammetry (SWV), which is designed to analyze the kinetics of the electron transfer step of surface mechanisms coupled with chemical reactions. We demonstrate with a series of simulated scenarios that caution must be taken when exploring the time-related analysis for kinetic characterizations for both surface CE and EC mechanisms. The main concern stems from the fact that the SW frequency simultaneously affects both the kinetics of electron transfer and that of chemical reactions as well. Under defined conditions, the SW frequency variation in the case of surface EC and CE mechanisms may produce unexpected features of the voltammetric patterns. In many scenarios, time-independent analysis, such as those related to the square-wave amplitude and potential increment, are seen as alternative tools to evaluate the rate parameter of electrode reactions.
\end{abstract}

Keywords: kinetics of electron transfer; surface $\mathrm{EC}_{\mathrm{rev}}$ mechanism; surface $\mathrm{C}_{\mathrm{rev}} \mathrm{E}$ mechanism; quasi-reversible maximum; square-wave voltammetry

\section{КРИТИЧКИ АСПЕКТИ ВО ПРИМЕНАТА НА ВРЕМЕНСКИ ЗАВИСНИТЕ АНАЛИЗИ НА ВОЛТАМЕТРИСКИТЕ МЕТОДИ ЗА ОПРЕДЕЛУВАЫЕ КИНЕТИЧКИ ПАРАМЕТРИ КАЈ ПОВРШИНСКИТЕ ЕЛЕКТРОДНИ МЕХАНИЗМИ ШТО СЕ ПОВРЗАНИ СО ХЕМИСКИ РЕАКЦИИ}

Прецизното определување на константите на брзина на трансфер на електрони кај „површински активните системи“ со примена на волтаметриски методи е од големо значење, бидејќ и вредностите на овие константи се директно поврзани со реактивноста и стабилноста на голем број важни биолошки и хемиски системи како што се „редокс“-ензимите, витамините, хормоните и многу други супстанции. Определувањето на кинетиката на електронски трансфер многу често е комплексен процес, посебно кога процесот на електронски трансфер е поврзан со хемиски рамнотежи. Во овој труд се анализирани повеќе критични аспекти на временски зависните анализи во услови на квадратно-бранова волтаметрија (SWV), дизајнирани за анализа на кинетиката на електронски трансфери на површински електродни механизми што се поврзани со 
хемиски реакции. Преку теоретските резултати од голем број симулации е покажано дека кога се работи за површински електродни механизми поврзани со претходна или последователна хемиска реакција (СЕ и ЕС механизми), потребно е со доза на голема претпазливост да се употребуваат временски зависните анализи за определување на кинетиката на електронските трансфери. Главниот проблем е што кај ваквите механизми фреквенцијата во квадратно-брановата волтаметрија истовремено влијае и врз кинетиката на електронскиот трансфер, но и врз кинетиката на хемиските реакции што се поврзани со електронскиот трансфер. При определени услови, фреквенцијата во SWV кај површинските ЕC и CE механизми може да предизвика неочекувани својства во волтаметриските одговори. Во голем број експериментални ситуации е потребно да се употребат алтернативни и временски независни анализи за определување на кинетиката на електронски трансфер, методи базирани на својствата на волтаметриските одговори на овие системи како функција од квадратно-брановата амплитуда или потенцијалниот инкремент.

Клучни зборови: кинетика на електронски трансфер; површински $\mathrm{EC}_{\mathrm{rev}}$ механизам; површински $\mathrm{C}_{\mathrm{rev}} \mathrm{E}$ механизам; квази-реверзибилен максимум; квадратно-бранова волтаметрија

\section{INTRODUCTION}

Cyclic voltammetry (CV) [1-3] and squarewave voltammetry (SWV) [4-8] are recognized as key electrochemical techniques for getting insights into electrode mechanisms, as well as for accessing kinetic and thermodynamic parameters of many biological and chemical systems. Both techniques are widely utilized in various areas of physics, chemistry, pharmacy, medicine, and biology. From the characteristics of cyclic and square-wave voltammograms, relevant information can be derived on adsorption, mass-transport, and charge-transfer phenomena that take place at the electrode/electrolyte interface [1-8]. Moreover, both techniques are very suitable for analyzing relevant aspects of chemical reactions that are coupled to the electron transfer process $[1,4]$. Analyzing these reactions is quite pertinent because they mimic important physiological processes, especially those in enzymatic biochemistry [9-15].

The theory of voltammetry aims to reveal the key parameters related to the kinetics and thermodynamics of electrode mechanisms which control the main features of the outcome of the voltammetric experiment. Estimation of the magnitude of the standard rate constant of the electron transfer step $k_{\mathrm{s}}{ }^{\ominus}$, most frequently considered in the frame of the Butler-Volmer formalism, encompasses one of the most important applications of $\mathrm{CV}$ and SWV [1-8]. The correlation of $k_{\mathrm{s}}{ }^{\ominus}$ with the energy difference of electrons between the orbitals of the working electrode and those of the analyzed electroactive species is critical for understanding the kinetics of many processes encountered in the redox chemistry of various systems $[1,2]$.

By combining the Butler-Volmer equation with modified Fick's laws for electrochemical reactions of dissolved species that are coupled with chemical reactions, one obtains implicit expressions that link the magnitude of the Faradaic current $(I)$ and the applied potential $(E)$, including parameters related to the kinetics and thermodynamics of the involved chemical processes. Theoretical simulation protocols under voltammetric conditions frequently involve dimensionless kinetic parameters. Such parameters are actually sort of normalized functions of the real rate constants (e.g., diffusion coefficient $(D)$, electrochemical standard rate constant $\left(k_{\mathrm{s}}{ }^{\ominus}\right)$, chemical rate constant $(k))$ and the critical time parameters of a particular voltammetric experiment (e.g., frequency $(f)$ in SWV or scan rate (v) in CV) $[1,2,4,5]$. A typical example is the electrode kinetic parameter of a quasi-reversible electrode reaction of a dissolved redox couple, defined as $K_{\mathrm{ET}}=k_{\mathrm{s}}{ }^{\ominus} /\left[(D f)^{1 / 2}\right]$, where the standard rate constant $k_{\mathrm{s}}{ }^{\theta}$, the diffusion coefficient $D$, and the time parameter $f$ are combined into a single parameter which predominantly determines electrochemical reversibility of an electrode reaction. In such an approach, the interpretation of theoretical data is generalized, revealing that the voltammetric outcome depends on the specific interrelation between the real system parameters.

For the majority of electrode processes, access to the kinetic parameters coupled with chemical equilibria is obtained by varying the scan rate $(v$, in CV) or frequency ( $f$ in SWV) [1-9]. However, such an approach hides the implicit danger related to the accuracy of the kinetic parameters obtained. This comes from the fact that the voltammetric response depends on several dimensionless parameters that are related to both electrode and chemical kinetics, while the time parameter is incorporated in all dimensionless kinetic parameters. Consequently, by varying time of the voltammetric experiment (i.e. $v$ or $f$ in $\mathrm{CV}$ and $\mathrm{SWV}$, respectively), one simultaneously affects the kinetics of all 
time-dependent parameters. This, in turn, can lead to misleading interpretations and erroneous estimations of the kinetic data. In this theoretical work, we illustrate this phenomenon by considering a few surface electrode mechanisms coupled with chemical reactions under the conditions of SWV. The aim of the study is to elucidate the best approach for analyzing voltammetric data for the purpose of adequate kinetic analysis when complex electrode mechanisms are considered.

\section{THEORETICAL MODELS}

Theoretical aspects of three, diffusionless, surface-confined electrode mechanisms are considered. They are described by the following reaction schemes:

A. Simple surface electrode reaction (E)

$$
\text { Ox(ads) }+ \text { ne- } \stackrel{\mathrm{k}_{\mathrm{s}}{ }^{\mathrm{C}}}{\longleftrightarrow} \operatorname{Red}(\mathrm{ads})
$$

B. Surface electrode reaction coupled with a preceding, reversible chemical reaction (surface $C_{\text {rev }}$ E mechanism)

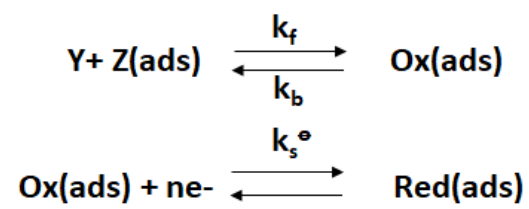

C. Surface electrode reaction associated with a reversible follow-up chemical reaction (surface $E C_{\text {rev }}$ mechanism)

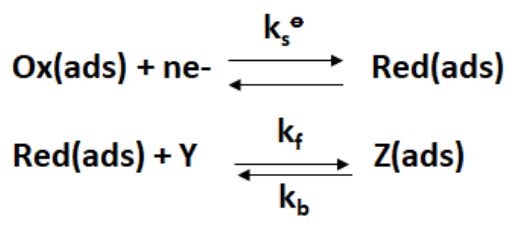

It is assumed that all immobilized species are distributed in the form of a monolayer on the working electrode surface. In addition, no lateral interactions of any kind exist between the immobilized species. The relevant recurrent formulas for calculating SW voltammograms of all three mechanisms are given elsewhere $[4,16]$. The symbol $\mathbf{Y}$ in schemes $(2,3)$ refers to the electrochemically inactive substrate that is present in a large excess. Since the surface concentration of $\mathbf{Y}$ is constant in the course of the experiment, the chemical step in reaction mechanisms $(2,3)$ is assumed to be pseudo-first order in terms of the chemical kinetics.
In the simulation of the voltammetric outcome, the reduction current is assigned to be positive, while the oxidation current is negative. The simulated data are presented in the form of a dimensionless current defined as $\Psi=I /\left(n F S f \Gamma^{*}\right)$. Here, $I$ is the symbol of the electric current, $n$ is the stoichiometric number of electrons, $S$ is the surface area of the working electrode, $f$ is the SW frequen$\mathrm{cy}$, and $\Gamma^{*}$ is the initial surface concentration of Ox(ads) species. The frequency of SWV is defined as $f=1 /\left(2 t_{p}\right)$, where $t_{p}$ is the duration of a single potential pulse [4].

In all mechanisms, the features of simulated voltammograms are a function of a dimensionless electrode kinetic parameter $K_{\mathrm{ET}}=k_{\mathrm{s}}{ }^{\ominus} / f$ that links the surface standard rate constant of the electron transfer $k_{\mathrm{s}}{ }^{\ominus}\left(\mathrm{s}^{-1}\right)$ with the SW frequency $f$. In addition, for both $\mathrm{C}_{\text {rev }} \mathrm{E}$ and $\mathrm{EC}_{\text {rev }}$ mechanisms (2-3), the voltammetric features depend on a dimensionless chemical kinetic parameter defined as $K_{\text {chem }}=$ $k_{\mathrm{c}} / f$. In the last equation, $k_{\mathrm{c}}$ is the cumulative rate constant of the chemical step, defined as $k_{\mathrm{c}}=\left(k_{\mathrm{f}}+\right.$ $k_{\mathrm{b}}$ ), where $k_{\mathrm{f}}$ and $k_{\mathrm{b}}$ are the rate constants of the forward and the backward chemical reactions, respectively. The physical meaning of $k_{\mathrm{c}}$ represents the rate at which the reversible chemical reaction can reach the equilibrium state, while the dimensionless parameter $K_{\text {chem }}$ reflects the kinetics of the reaction relative to the time-frame of SWV. Furthermore, the voltammetric patterns of both $\mathrm{C}_{\mathrm{rev}} \mathrm{E}$ and $\mathrm{EC}_{\text {rev }}$ mechanisms are affected by the equilibrium constant of the chemical reaction, which is defined as $K_{\mathrm{eq}}=k_{\mathrm{f}} / k_{\mathrm{b}}$, representing the state of the established chemical equilibrium.

If not otherwise stated, the parameters of applied potential were set to the following values: SW amplitude $E_{\mathrm{sw}}=50 \mathrm{mV}$, step potential $\mathrm{d} E=4$ $\mathrm{mV}$, and frequency $f=10 \mathrm{~Hz}$, while the electron transfer coefficient was set to $\alpha=0.5$. More details of the algorithms used can be found in $[4,7,8,16]$. The commercial software package MATHCAD 14 was used for calculation of all theoretical voltammograms.

\section{RESULTS AND DISCUSSION}

\subsection{A short overview of some relevant voltammetric methods for evaluation of the rate of the electron transfer}

Cyclic voltammetry is often explored as a reliable tool to get insights into the mechanism of various electrochemical systems [1-3]. Moreover, a plethora of methods with $\mathrm{CV}$ have been reported 
to access the relevant kinetic data, as well $[1,2]$. The methods of Nicholson [17], Gileadi [18], Kochi [19], Saveant [20] and Laviron [21] rely on the scan rate analysis of either the peak-to-peak potential separation or the mid-peak potential of cyclic voltammograms. For a simple electrode reaction of a dissolved redox couple, SWV also enables determination of the kinetics of the heterogeneous electron transfer based on the frequency analysis of the net-peak potential [4]. In addition, several alternative SWV methods allow access to the kinetic parameters of the heterogeneous electron transfer $[4,8,22]$.

When the surface electrode mechanisms are concerned, SWV offers a variety of approaches to determine electrode kinetic parameters $[4,7,8,23-$ 31]. Next to the net-peak potential $v s$. frequency analysis [4, 20], a plethora of methods have been developed based on the analysis of the net-peak current (Fig. S1) and the potential separation between split net-peak (Figs. S2 and S3) as a function of the frequency $[4,8,16]$. Moreover, kinetic analysis can be conducted by varying the SW amplitude at a constant SW frequency, i.e. at the constant scan rate of the voltammetric experiment [4, 27]. Relevant methods for accessing the kinetics of electron transfer reactions in SWV at constant scan rate are reported in [29-31]. These methods rely on amplitude-based quasi-reversible maximum [29] or kinetic evaluations at constant scan rate that are evaluated from the peak potentials of forward and backward currents as a function of the SW amplitude [30, 31].

\subsection{Implications of the time analysis for surface $C_{r e v} E$ and $E C_{r e v}$ mechanisms in SWV}

When the time analysis is performed to estimate kinetic parameters of electrochemical systems coupled with preceding or follow-up chemical reactions, the situation gets far more complicated. It is worth emphasizing that for a simple surface electrode reaction an increase of the kinetic parameter of the electron transfer step $K_{\mathrm{ET}}$ is commonly followed by a shift of the net-peak potential to more positive values for an overall reductive electrode mechanism. For the surface $\mathrm{C}_{\mathrm{rev}} \mathrm{E}$ mechanism, an increase of the chemical parameter $K_{\text {chem }}$ causes a shift of the net-peak potential to more negative values, assuming a "constant value" of $K_{\mathrm{ET}}$, as reported in $[16,25]$. From the definition of both $K_{\mathrm{ET}}$ and $K_{\text {chem }}\left(K_{\mathrm{ET}}=k_{\mathrm{s}}{ }^{\ominus} / f\right.$ and $\left.K_{\text {chem }}=k_{\mathrm{d}} / f\right)$, it follows that the SW frequency affects these parameters equally. However, the two dimensionless parameters exhibit an effect opposite to the net-peak potential $\left(E_{\text {net,p }}\right)$. Therefore, one expects that the frequency analysis will cause complex voltammetric features, which might be additionally affected by the magnitude the equilibrium constant $K_{\text {eq. }}$.

Several theoretical curves referring to $E_{\text {net,p }}$ vs. $\log (1 / f)$ function are shown in Figure 1. These were calculated by assuming a constant value of $K_{\text {chem }}=100$ for three different values of the equilibrium constant of the preceding chemical reaction. This analysis reveals the partial influence of the frequency which is manifested through the electrode kinetic parameter only.

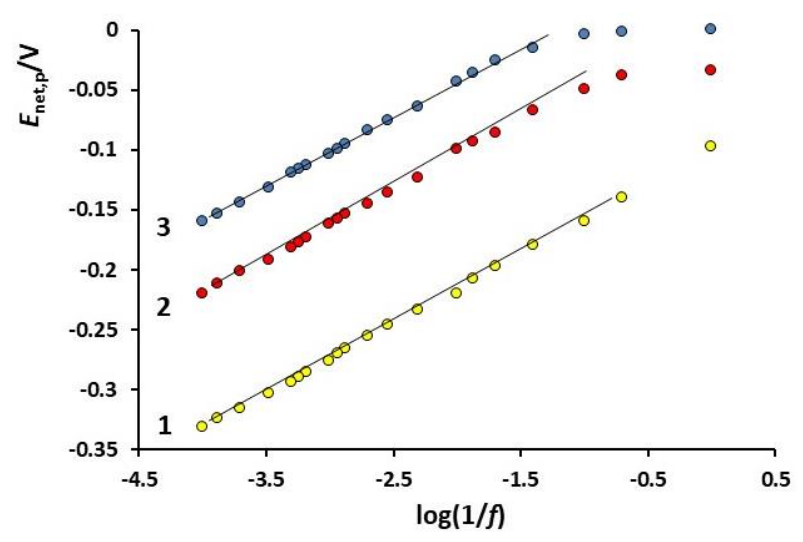

Fig. 1. Surface $\mathrm{C}_{\mathrm{rev}} \mathrm{E}$ mechanism. The net-peak potential $E_{\text {net,p }}$ as a function of the logarithm of the inverse SW frequency. Voltammetric curves are simulated by assuming a constant value of the dimensionless chemical rate parameter $K_{\text {chem }}=$ 100 . The other simulation conditions were: standard rate constant $k_{\mathrm{s}}{ }^{\ominus}=0.794 \mathrm{~s}^{-1}$, electron transfer coefficient $\alpha=0.5$, SW amplitude $E_{\mathrm{sw}}=50 \mathrm{mV}$, step potential $\mathrm{d} E=4 \mathrm{mV}$, temperature $T=298 \mathrm{~K}$, and the stoichiometric number of electrons $n=$ 2 . The values of the equilibrium constant of the preceding chemical reaction are $K_{\mathrm{eq}}=0.001(\mathbf{1}), 0.1(2)$, and $100(\mathbf{3})$.

However, when an electrode mechanism is studied in a real experiment, the frequency simultaneously affects both kinetic parameters $K_{\mathrm{ET}}$ and $K_{\text {chem }}$. Hence, the frequency might produce rather complex voltammetric outcomes, as shown by exemplary voltammetric patterns, Figure 2, calculated for a typical quasi-reversible electrode reaction. For $K_{\mathrm{eq}} \leq 10^{-3}$, one observes almost a constant position of the netpeak by increasing the frequency (Fig. 2), while the forward and backward voltammetric components exhibit typical evolution of a quasi-reversible reaction under increasing frequency $[4,25]$. 

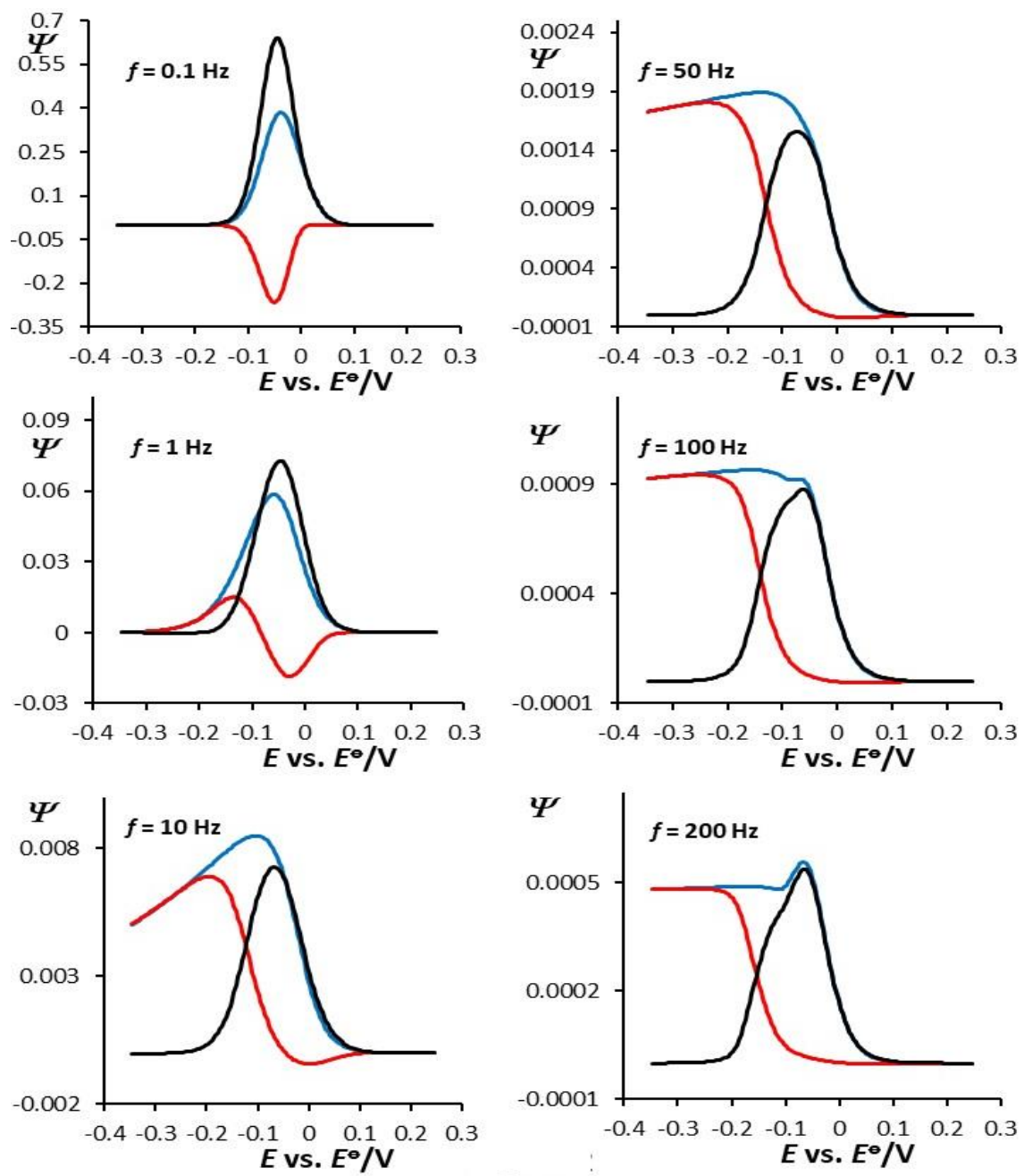

Fig. 2. Surface $\mathrm{C}_{\mathrm{rev}} \mathrm{E}$ mechanism. Evolution of the $\mathrm{SW}$ voltammetric patterns by increasing the $\mathrm{SW}$ frequency (the values are given in the plot) for the standard rate constant $k_{\mathrm{s}}{ }^{\theta}=0.794 \mathrm{~s}^{-1}$, equilibrium constant $K_{\text {eq }}=0.001$, and the cumulative chemical rate constant $k_{\mathrm{c}}=100 \mathrm{~s}^{-1}$. Other conditions of the simulations are identical as for Figure 1. In all voltammograms, the forward (reduction), backward (oxidation), and net current are depicted with blue, red, and black colors, respectively.

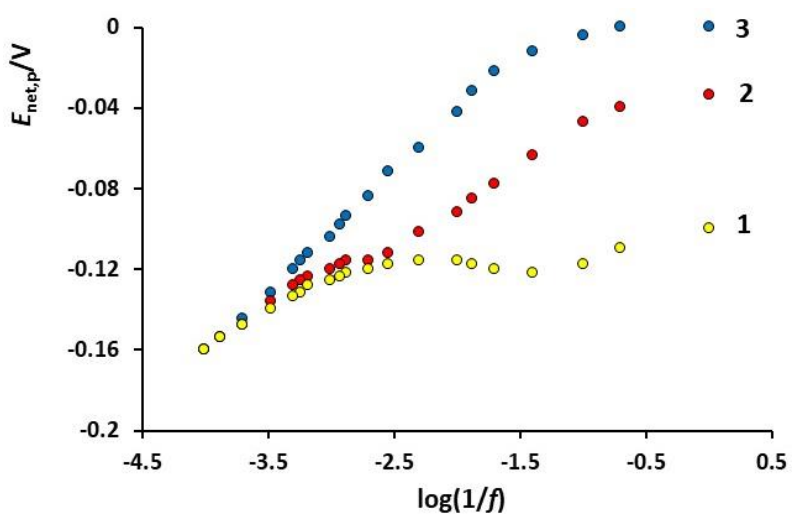

Fig. 3. Surface $\mathrm{C}_{\mathrm{rev}} \mathrm{E}$ mechanism. Dependence of the net-peak potential $E_{\text {net,p }}$ on the logarithm of the inverse SW frequency. The simulation conditions are as follows: standard rate constant $k_{\mathrm{s}}{ }^{\ominus}=0.794 \mathrm{~s}^{-1}$, cumulative chemical rate constant $k_{\mathrm{c}}=100 \mathrm{~s}^{-1}, \mathrm{SW}$ amplitude $E_{\mathrm{sw}}=50 \mathrm{mV}$, and step potential $\mathrm{d} E$ $=4 \mathrm{mV}$. The values of the equilibrium constant are $K_{\mathrm{eq}}=$ $0.001(\mathbf{1}) ; 0.1(2)$ and $100(3)$. Other conditions of the simulations are identical as for Figure 1.
Shown in Figure 3 are the dependences between the net-peak potential $E_{\text {net, }} v s . \log (1 / f)$, simulated for $k_{\mathrm{s}}{ }^{\theta}=0.794 \mathrm{~s}^{-1}, k_{\mathrm{c}}=100 \mathrm{~s}^{-1}$ and for three values of $K_{\text {eq. }}$. The complex functional dependence of $E_{\text {net,p }} v s . \log (1 / f)$ is a consequence of the simultaneous variation of $K_{\mathrm{ET}}$ and $K_{\text {chem }}$ by the SW frequency. These findings imply that the $E_{\text {net,p }} v s . f$ function can hardly be exploited to estimate $k_{\mathrm{s}}{ }^{\theta}$ or $k_{\mathrm{c}}$ of a surface $\mathrm{C}_{\mathrm{rev}} \mathrm{E}$ system. The same holds true for the $\mathrm{EC}_{\text {rev }}$ mechanism (cf. Fig. 4).

As elaborated in [4], a simple and efficient tool to measure the kinetics of the electron transfer of a simple surface electrode mechanism is the feature named "quasi-reversible maximum" (QRM), which is based on the analysis of the net-peak current. The parabolic dependence of the net-peak current as a function of $\log (1 / f)$ can provide access to the standard rate constant of the electron transfer in a very simple manner [4], provided the electron transfer coefficient $\alpha$ is previously determined. 
The last parameter $(\alpha)$ can be evaluated from the half-peak width of square-wave voltammograms $v s$ temperature dependence, performed in the regions of very slow electron transfer (i.e. at large frequencies) and following the methodology elaborated in [22]. Alternatively, the electron transfer coefficient $\alpha$ can also be evaluated from the features of split SW peaks at fast electrode reactions, as explained in [4].

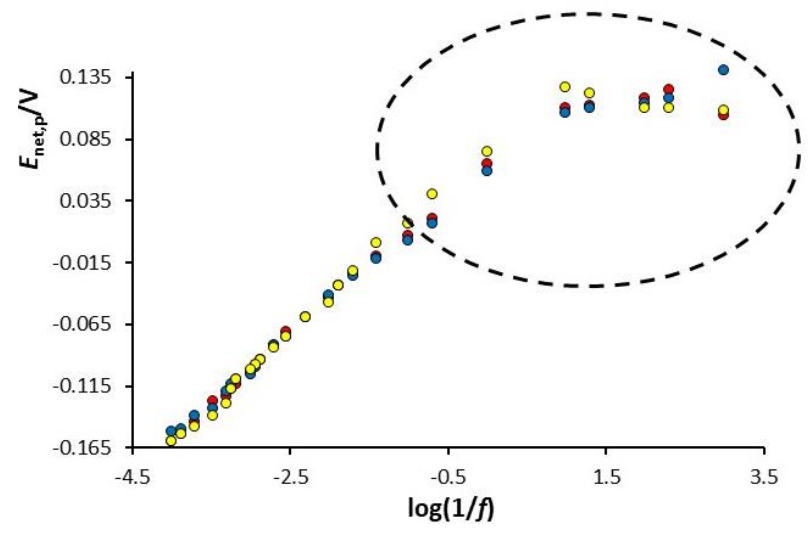

Fig. 4. Surface $\mathrm{EC}_{\mathrm{rev}}$ mechanism. Dependence of the net-peak potential $E_{\text {net,p }}$ on the logarithm of the inverse SW frequency. The simulation conditions are as follows: standard rate constant $k_{\mathrm{s}}{ }^{\theta}=$ $0.794 \mathrm{~s}^{-1}$, cumulative chemical rate constant $k_{\mathrm{c}}=1 \mathrm{~s}^{-1}, \mathrm{SW}$ amplitude $E_{\mathrm{sw}}=50 \mathrm{mV}$, and step potential $\mathrm{d} E=4 \mathrm{mV}$. The values of the equilibrium constant are $K_{\mathrm{eq}}=0.001$ (red circles); 1 (blue circles), and 100 (yellow circles). Other conditions of the simulations are identical to those described in Figure 1.

The evolution of QRM as a function of chemical kinetics, simulated for the surface $\mathrm{C}_{\mathrm{rev}} \mathrm{E}$ mechanism, is depicted in Figure 5. In a broad context, the position of the QRM is sensitive to multiple parameters, including the SW amplitude $\left(E_{\mathrm{sw}}\right)$, step potential $(\mathrm{d} E)$, electron transfer coefficient $(\alpha)$, and the equilibrium constant $\left(K_{\mathrm{eq}}\right)$. Comprehensive simulations revealed that the QRM emerges for the $\mathrm{C}_{\mathrm{rev}} \mathrm{E}$ mechanism if the preceding chemical reaction is associated with $K_{\text {eq }}>0.01$ and $K_{\text {chem }}$ $>0.05$. It is important to point out that for the conditions of Figure 5 the position of the QRM is virtually independent of the chemical rate parameter $k_{\mathrm{c}}$. Furthermore, in a broad interval of $k_{\mathrm{c}}$ values, the position of the QRM is slightly dependent on $K_{\text {eq }}$, as shown in Figure 6. Hence, the data presented in Figures 5 and 6 imply that the QRM is a suitable feature for estimating the standard rate constant of the electron transfer $\left(k_{\mathrm{s}}{ }^{\theta}\right)$, in spite of the fact that the kinetic and thermodynamic parameters of the preceding chemical reaction of the $\mathrm{C}_{\mathrm{rev}} \mathrm{E}$ mechanism are not exactly known, which is valid for $\log \left(K_{\mathrm{eq}}\right) \geq-2$ and for large range of $k_{\mathrm{c}}$ values.
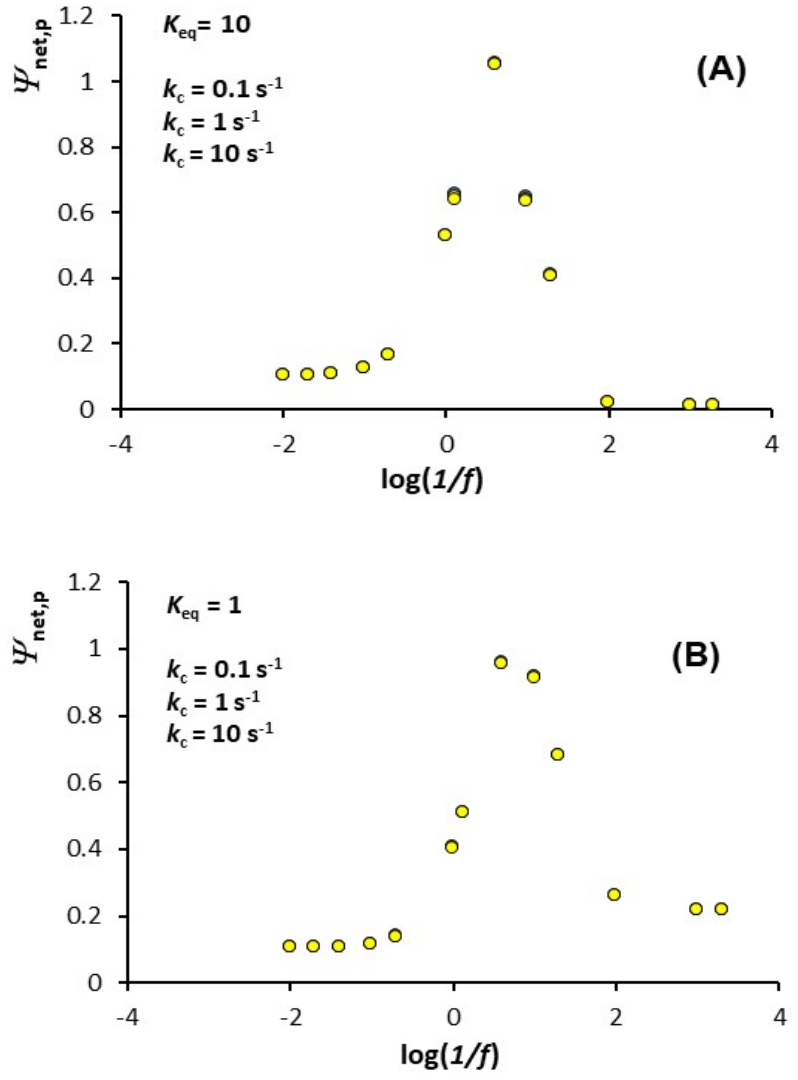

Fig. 5. Surface $\mathrm{C}_{\mathrm{rev}} \mathrm{E}$ mechanism. Dependence of the net-peak current $\Psi_{\text {net,p }}$ on the logarithm of the inverse SW frequency, simulated for different values of the cumulative chemical rate constant $k_{\mathrm{c}}$. The simulation conditions are as follows: standard rate constant $k_{\mathrm{s}}{ }^{\theta}=0.1 \mathrm{~s}^{-1}$, step potential $\mathrm{d} E=4 \mathrm{mV}$, and the equilibrium constants are $K_{\mathrm{eq}}=10$ (for panel $\mathbf{A}$ ) and 1 (for panel $\mathbf{B})$. Other conditions of the simulations are identical to those described in Figure 1.

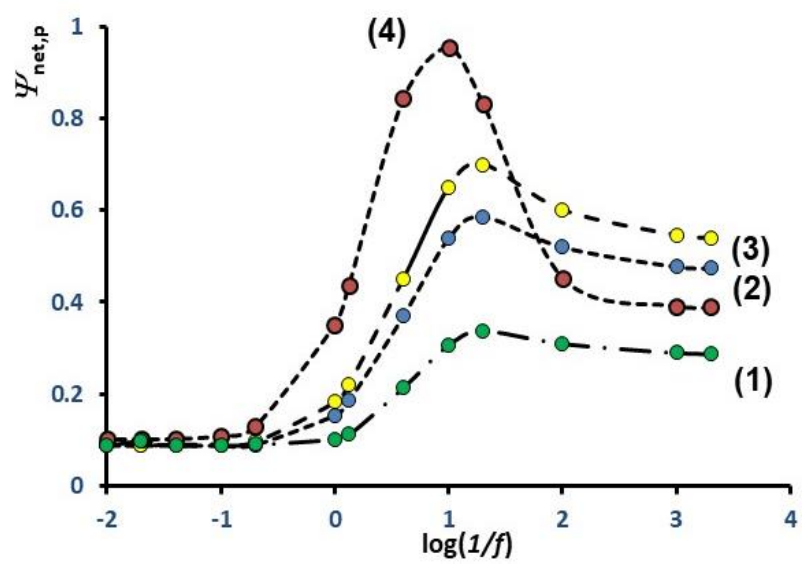

Fig. 6. Surface $\mathrm{C}_{\mathrm{rev}} \mathrm{E}$ mechanism. Dependence of the net-peak current $\Psi_{\text {net,p }}$ on the logarithm of the inverse SW frequency, calculated for different values of the equilibrium constant: $K_{\mathrm{eq}}$ $=0.03(\mathbf{1}) ; 0.07(\mathbf{2}) ; 0.1(3)$ and $0.56(\mathbf{4})$. The simulation conditions are: standard rate constant $k_{\mathrm{s}}{ }^{\ominus}=0.1 \mathrm{~s}^{-1}$ and the cumulative chemical rate constant $k_{\mathrm{c}}=1 \mathrm{~s}^{-1}$. Other conditions of the simulations are identical to those described in Figure 1. 
For the surface $\mathrm{EC}_{\mathrm{rev}}$ mechanism, however, quite a different evolution of the QRM was observed for different values of $k_{\mathrm{c}}$, particularly in the region of moderate-to-low values of $K_{\text {eq }}[16,28]$. An increase of the chemical rate parameter $k_{\mathrm{c}}$ (roughly, within the region $0.1 \mathrm{~s}^{-1}<k_{\mathrm{c}}<10 \mathrm{~s}^{-1}$ ) affects not only the position but also the shape of the QRM (Fig. 7). In some regions of SW frequency, one observes so-called "local maximums" which appear due to the specific interplay of $k_{\mathrm{s}}{ }^{\ominus}, k_{\mathrm{c}}$, and $K_{\text {eq. }}$. These findings suggest that the rate of the chemical step might significantly influence the rate of the electron transfer step for the $\mathrm{EC}_{\text {rev }}$ system, especially those featuring moderate and low values of the equilibrium constant.

The reasons for this complex behavior associated with the complex evolution of the backward component of the SW voltammogram are partly elaborated elsewhere [28, 32]. The features of the QRM of the surface $\mathrm{EC}_{\text {rev }}$ mechanism are a consequence of the specific chronoamperometric features of this mechanism. They are significantly affected by the proceeding of the follow-up chemical reaction within the so-called "dead time" of potential pulses, where the current is not measured $[28,32]$. The phenomenon depicted in Figure 7 is quite different from the surface $\mathrm{C}_{\mathrm{rev}} \mathrm{E}$ mechanism. It implies that the kinetic analysis by varying the SW frequency (i.e. time analysis) for the surface $\mathrm{EC}_{\text {rev }}$ mechanism by means of the $\mathrm{QRM}$ is not straightforward. In addition, the effect of the equilibrium constant on the position and morphology of the QRM is rather complex, as illustrated in Figure 8.

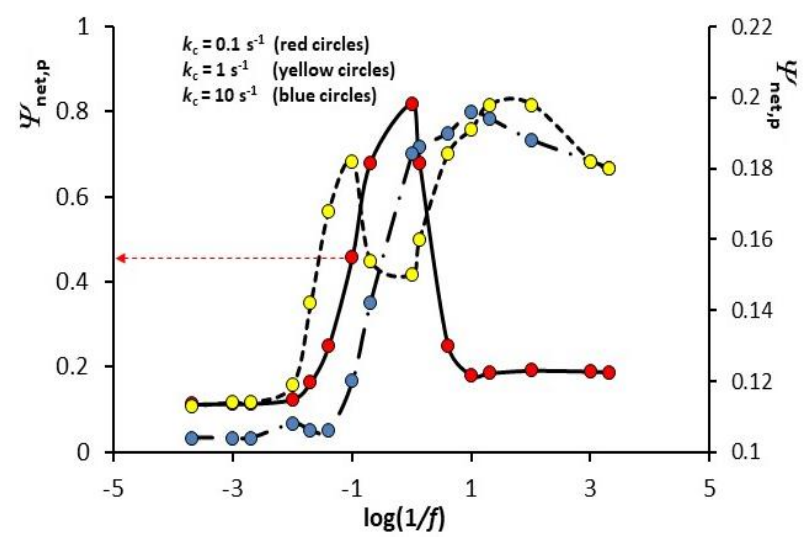

Fig. 7. Surface $\mathrm{EC}_{\mathrm{rev}}$ mechanism. Dependence of the net-peak current $\Psi_{\text {net,p }}$ on the logarithm of the inverse SW frequency, calculated for different values of the cumulative chemical rate constant $k_{\mathrm{c}}$ (the values of $k_{\mathrm{c}}$ are given on the plot); the equilibrium constant is $K_{\mathrm{eq}}=0.01$, and the standard rate constant is $k_{\mathrm{s}}{ }^{\theta}=10 \mathrm{~s}^{-1}$. The curves with yellow and blue circles refer to the right ordinate. Other conditions of the simulations are identical to those described in Figure 1.

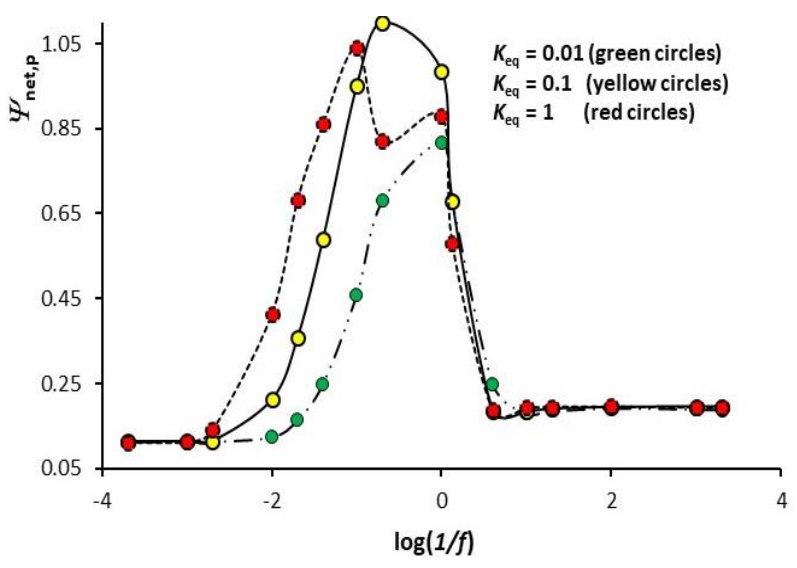

Fig. 8. Surface $\mathrm{EC}_{\mathrm{rev}}$ mechanism. Dependence of the net-peak current $\Psi_{\text {net,p }}$ on the logarithm of the inverse SW frequency for different values of the equilibrium constant $K_{\text {eq }}$ given on the plot. The standard rate constant is $k_{\mathrm{s}}{ }^{\theta}=10 \mathrm{~s}^{-1}$ and the cumulative chemical rate constant is $k_{\mathrm{c}}=0.1 \mathrm{~s}^{-1}$. Other conditions of the simulations are identical to those described in Figure 1.

In previous studies [16, 28], it has been elaborated that the feature known as "split net SW peak" of the surface $\mathrm{C}_{\mathrm{rev}} \mathrm{E}$ and $\mathrm{EC}_{\mathrm{rev}}$ mechanisms is also sensitive to the value of $K_{\text {chem }}$ and $K_{\text {eq }}$. Consequently, the estimation of the standard rate constant based on the split net SW peak must be taken with a caution, when the analysis is done by altering the $\mathrm{SW}$ frequency, for both $\mathrm{C}_{\mathrm{rev}} \mathrm{E}$ and $\mathrm{EC}_{\text {rev }}$ mechanisms. However, it is worth mentioning that the analysis of the splitting of net-peak by altering the substrate concentration can be effectively explored as a diagnostic criterion to characterize both surface $\mathrm{EC}_{\mathrm{rev}}$ and $\mathrm{C}_{\mathrm{rev}} \mathrm{E}$ mechanisms featuring very fast kinetics of the electron transfer step [16].

\section{CONCLUSIONS}

Although the surface electrode mechanisms coupled with either preceding or following chemical reactions are well elaborated under conditions of SWV [4, 8, 15, 16, 25, 28, 32], some aspects of these systems need to be taken into critical consideration. Many theoretical voltammetric methods that were developed to get access to the kinetics of a wide diversity of redox systems coupled with chemical reactions rely on the time-analysis of some relevant voltammetric parameters $[1-3,20$, $21]$. If the time-analysis is performed to get an access to the kinetics of electrode reactions associated with chemical equilibria in SWV, caution must be taken about the methodology used. For the surface $\mathrm{C}_{\mathrm{rev}} \mathrm{E}$ mechanism, the quasi-reversible maximum based on the frequency variation can be successfully explored for estimation of the standard rate constant $k_{\mathrm{s}}{ }^{\theta}$ without previous knowledge of the ki- 
netics and thermodynamics of the chemical reaction, in a broad interval of values for both $k_{\mathrm{c}}$ and $K_{\text {eq }}$. This is not the case, however, for the surface $\mathrm{EC}_{\mathrm{rev}}$ mechanism, where the kinetics of the electrode reaction can be significantly affected by the kinetics of the follow-up chemical step. Minimization of some of the effects caused by the rate of the follow up chemical reaction can be eventually avoided by performing experiments at frequencies larger than $100 \mathrm{~Hz}$, preferably between $100 \mathrm{~Hz}$ and $500 \mathrm{~Hz}$. Alternatively, methods based on the constant time of the experiment (i.e., constant scan rate of the voltammetry) are recommended $[29,30]$ to access the kinetics of electrode reaction by using square-wave amplitudes between $25 \mathrm{mV}$ and $100 \mathrm{mV}$. It is important to stress that the phenomenon of net-peak splitting might be significantly affected by the kinetics of the chemical reaction for both $\mathrm{C}_{\mathrm{rev}} \mathrm{E}$ and $\mathrm{EC}_{\mathrm{rev}}$ mechanisms. This phenomenon, however, can be explored as a simple tool for qualitative differentiation between $\mathrm{C}_{\mathrm{rev}} \mathrm{E}$ and $\mathrm{EC}_{\text {rev }}$ mechanisms [16]. In the end, it is worth mentioning that the need of a theoretical study, such as the one presented in this work, has been implicitly addressed in two recent theoretical papers by Molina, Compton et al. [34, 35].

Acknowledgments: Rubin Gulaboski thanks the Goce Delčev University in Štip for the support. Valentin Mirčeski acknowledges with gratitude the support through the NATO Grant No. SPS G5550.

\section{REFERENCE}

[1] R. G. Compton, C. E. Banks, Understanding Voltammetry, $2^{\text {nd }}$ Edition, Imperial College Press, London, UK, 2011.

[2] A. J. Bard, L. R. Faulkner, Electrochemical Methods. Fundamentals and Applications, $3^{\text {rd }}$ edition, John Wiley \& Sons Inc., 2004.

[3] D. K. Gosser, Cyclic Voltammetry: Simulation and Analysis of Reaction Mechanisms, VCH, New York, USA, 1993.

[4] V. Mirčeski, S. Komorsky-Lovrić, M. Lovrić, Squarewave Voltammetry: Theory and Application, (Scholz F. ed.), $2^{\text {nd }}$ ed., Berlin, Springer, 2007.

[5] A. Molina, J. Gonzales, Pulse Voltammetry in Physical Electrochemistry and Electroanalysis. In: Monographs in Electrochemistry (F. Scholz, ed.), Berlin-Heidelberg, Springer, 2016.

[6] J. G. Osteryoung, J. J. O'Dea, Square-Wave Voltammetry, Electroanalytical Chemistry: A series of Advances, Marcel Dekker, Inc., New York, 1986.

[7] V. Mirčeski, R. Gulaboski, Recent achievements in square-wave voltammetry (a review), Maced. J. Chem. Chem. Eng., 33, 1-12 (2014).

[8] V. Mirčeski, R. Gulaboski, M. Lovrić, I. Bogeski, R. Kappl, M. Hoth, Square-wave voltammetry - a review on the recent progress, Electroanal., 25, 2411-2422 (2013). DOI: https://doi.org/10.1007/s10008-011-1397-5

[9] F. A. Arsmstrong, Electrifying metalloenzymes. In: Metalloproteins: Theory, calculations and experiments (A. E. Cho, W. A Goddar, eds), CRC Press, Taylor\&Francis Group, London, New York (2015).

[10] F. A. Armstrong, Voltammetry of proteins. In: Encyclopedia of Electrochemistry (A. J. Bard, Stratmann, M, Wilson GS, eds), Vol. 9, Wiley VCH, Weinheim, 2002.

[11] F. A. Armstrong, Applications of Voltammetric Methods for Probing the Chemistry of Redox Proteins. In: Bioelectrochemistry: Principles and Practice (G. Lenaz, G. Milazzo, eds.), Vol. 5, Birkhauser Verlag AG, Basel, 1997.

[12] F. A. Armstrong, H. A. Heering, J. Hirst, Reactions of complex metalloproteins studied by protein-film voltammetry, Chem. Soc. Rev., 26, 169-179 (1997).

[13] C. Leger, P. Bertrand, Direct electrochemistry of redox enzymes as a tool for mechanistic studies, Chem. Rev., 108, 2379-2438 (2008). DOI: doi.org/10.1021/cr0680742

[14] R. Gulaboski, V. Mirčeski, Application of voltammetry in biomedicine - recent achievements in enzymatic voltammetry, Maced. J. Chem. Chem. Eng., 39, 153-166 (2020). DOI: $10.20450 /$ mjcce.2020.2152

[15] R. Gulaboski, V. Mirčeski, I. Bogeski, M. Hoth, Proteinfilm voltammetry: electrochemical enzymatic spectroscopy. A review on recent progress. J. Solid State Electrochem., 16, 2315-2328 (2012). DOI: https://doi.org/10.1007/s10008-011-1397-5

[16] R. Gulaboski, V. Mirčeski, M. Lovrić, Square-wave protein-film voltammetry: new insights in the enzymatic electrode processes coupled with chemical reactions, $J$. Solid State Electrochem., 23, 2493-2506 (2019). DOI: https://doi.org/10.1007/s10008-019-04320-7

[17] R. S. Nicholson, Theory and application of cyclic voltammetry for measurement of electrode reaction kinetics, Anal. Chem., 37, 1351-1355 (1965).

[18] E. Gileadi, Charge and mass transfer across the metal/solution interface, Israel J. Chem., 48, 121-131 (2008). DOI: https://doi.org/10.1560/IJC.48.3-4.121

[19] R. J. Klinger, J. K. Kochi, Electron transfer kinetics from cyclic voltammetry. Quantitative description of electrochemical reversibility, J. Phys. Chem., 85, 17311741 (1981).

[20] J. M. Saveant, Elements of Molecular and Biomolecular Electrochemistry: An Electrochemical Approach to Electron Transfer Chemistry, John Wiley \& Sons, 2006. DOI:10.1002/0471758078

[21] E. Laviron, General expressions of the linear potential sweep voltammogram in case of difussionless electrochemical systems. J. Electroanal. Chem., 101, 19-28 (1979).

[22] R. Gulaboski, M. Lovrić, V. Mirčeski, I. Bogeski, A new rapid and simple method to determine the kinetics of electrode reactions of biologically relevant compounds from the half-peak width of the square-wave voltammograms, Biophys. Chem., 138, 130-137 (2008). DOI: 10.1016/j.bpc.2008.09.015

[23] R. Gulaboski, V. Mirčeski, I. Bogeski, M. Hoth, Proteinfilm voltammetry: electrochemical enzymatic spectros- 
copy. A review on recent progress, J. Solid State Electrochem., 16, 2315-2328 (2012).

DOI: https://doi.org/10.1007/s10008-011-1397-5

[24] V. Mirčeski, R. Gulaboski, Surface catalytic mechanism in square-wave voltammetry. Electroanal., 13, 13261334 (2001).

[25] R. Gulaboski, V. Mirčeski, M. Lovrić, I. Bogeski, Theoretical study of a surface electrode reaction preceded by a homogeneous chemical reaction under conditions of square-wave voltammetry. Electrochem. Commun., 7, 515-522 (2005).

[26] V. Mirčeski, R. Gulaboski, The surface catalytic mechanism: a comparative study with square-wave and cyclic staircase voltammetry, J. Solid State Electrochem., 7, 157-165 (2003).

[27] V. Mirčeski, M. Lovrić, Split square-wave voltammograms of surface redox reactions. Electroanal., 9, 12831287 (1997).

[28] R. Gulaboski, M. Janeva, V. Maksimova, New aspects of protein-film voltammetry of redoxenzymes coupled to follow-up reversible chemical reaction in square-wave voltammetry, Electroanal., 31, 946-956 (2019). DOI: https://doi.org/10.1002/elan.201900028

[29] V. Mirčeski, E. Laborda, D. Guziejewski, R. Compton, New approach to electrode kinetic measurements in square-wave voltammetry: amplitude-based quasireversible maximum. Anal. Chem., 85, 5586-5594 (2013). DOI:10.1021/ac40008573
[30] V. Mirčeski, D. Guziejewski, K. Lisichkov, Electrode kinetics measurements with square-wave voltammetry at a constant scan rate. Electrochim. Acta 114, 667-673 (2013). DOI: https://doi.org/10.1016/j.electacta.2013.10.046

[31] D. Guziejewski, V. Mirčeski, D. Jadresko, Measuring the electrode kinetics of surface confined electrode reactions at constant scan rate, Electroanal. 27, 67-73 (2015). DOI: https://doi.org/10.1002/elan.201400349

[32] R. Gulaboski, Theoretical contribution towards understanding specific behaviour of "simple" proteinfilm reactions in square-wave voltammetry. Electroanal., 31, 545-553 (2019). https://onlinelibrary.wiley.com/doi/10.1002/elan.201800 739

[33] R. Gulaboski, V. Mirčeski, New aspects of the electrochemical-catalytic (EC') mechanism in square-wave voltammetry, Electrochim. Acta 167, 219-225 (2015). DOI: https://doi.org/10.1016/j.electacta.2015.03.175

[34] M. Lopez-Tenes, E. Laborda, A. Molina, R. Compton, Guidelines for the voltammetric study of electrode reactions with coupled chemical kinetics at an arbitrary electrode geometry, Anal. Chem., 91, 6072-6079 (2019). DOI:10.1021/acs.analchem.9b00616

[35] A. Molina, M. Lopez-Tenes, E. Laborda, Unified theoretical treatment of the $\mathrm{E}_{\text {irrev }}, \mathrm{EC}, \mathrm{CE}$ and CEC mechanisms under voltammetric conditions, Electrochem. Commun., 98, 48-55 (2018). DOI: $10.1016 /$ j.elecom.2018.03.011 
